\title{
KASUS BULLYING DALAM KALANGAN PELAJAR (SUATU TINJAUAN KRIMINOLOGI)
}

\author{
Oleh : \\ Nunuk Sulisrudatin, SH, SIP, MSI. \\ Dosen Tetap Fakultas Hukum \\ Universitas Suryadarma Jakarta. \\ Email : (bununux@gmail.com)
}

\begin{abstract}
Abstrak:
Akhir-akhir ini berita kasus bullying di Indonesia kembali muncul ke permukaan. Berita kasus bullying di sebuah sekolah menengah atas di Jakarta seakan menjadi fokus pembahasan media massa dalam negeri. Seakan rantai yang tak pernah putus, bullying terus mewarnai dunia pendidikan Indonesia tanpa pengentasan serius. Sebenarnya bullying bukan hanya ada dalam dunia pendidikan, tetapi juga dalam keluarga, dunia kerja, dan lain-lain. Apalagi di dunia anak jalanan, betapa anak-anak itu seringkali dibully oleh preman-preman yang lebih tua dan kekar perawakannya. Ini semua seakan menyadarkan kita betapa bullying sudah menjadi masalah global yang serius. Tindak pencegahan sejak dini melalui pendidikan moral, penerapan hidup bersama yang penuh kekeluargaan dan tanggung jawab, serta penataan hukum menjadi langkah awal efektif untuk mengurangi tindak bullying di masyarakat. Tindak penyelesaian melalui jalur hukum tentu langkah terakhir dan dibutuhkan kerjasama serta dilaksanakan secara terus-menerus oleh semua pihak tanpa terkecuali, mulai dari diri sendiri, keluarga, masyarakat, dan negara..
\end{abstract}

\section{[PENDAHULUAN]}

Di Indonesia berbagai kasus bully sudah tidak asing terdengar di telinga para pengamat media massa. News anchor membacakan melalui media elektronik televisi, penyiar menjelaskan melalui media elektronik radio, dan para wartawan menuliskannya di berbagai surat kabar. Seringkali hukum dan pemerintah kurang cepat dan cermat dalam menangani kasus bully di Indonesia. Akhirnya pelaku dan korban bully terus bertambah seiring berjalannya waktu. Semakin banyak yang jahat, semakin banyak pula yang tertindas. Bullying itu sendiri adalah tindakan mengintimidasi seseorang melalui sikap, tindakan, dan perkataan. Jadi, bullying tidak terbatas pada penyiksaan secara fisik, tetapi juga psikis. Mengucilkan dan menggosipkan seseorang juga termasuk tindakan bullying.

Menurut Sekretaris Komisi Perlindungan Anak Indonesia (KPAI), Erlinda, selama Januari hingga April sudah tercatat 8 laporan kekerasan serupa, yaitu 2 kasus di Sekolah Dasar (SD), 2 kasus di Sekolah Menengah Pertama (SMP) dan sisanya di Sekolah Menengah Atas (SMA). Dari hasil penelitian KPAI ternyata sebanyak $17 \%$ kekerasan terhadap anak terjadi di sekolah. Bahkan pada 2013, tercatat 181 kasus yang berujung pada tewasnya korban, 141 kasus 
korban menderita luka berat, dan 97 kasus korban luka ringan. Tindakan kekerasan di sekolah bisa dilakukan oleh guru, kepala sekolah, bahkan sesama peserta didik. ${ }^{1}$

Kasus bullying di sekolah menduduki peringkat teratas pengaduan masyarakat ke Komisi Perlindungan Anak Indonesia (KPAI) di sektor pendidikan. Dari 2011 sampai Agustus 2014, KPAI mencatat 369 pengaduan terkait masalah tersebut. Jumlah tersebut sekitar 25 persen dari total pengaduan di bidang pendidikan sebanyak 1.480 kasus. Bullying yang disebut KPAI sebagai bentuk kekerasan di sekolah mengalahkan tawuran pelajar, diskriminasi pendidikan, ataupun aduan pungutan liar. KPAI mengklasifikasikan aduan kekerasan anak berdasarkan bidang, selain pendidikan, ada sembilan sektor lainnya termasuk pornografi, kesehatan, dan eksploitasi anak. Total dari 2011 sampai Agustus 2014 mencapai 12.790 aduan. $^{2}$ Berikut ini disajikan tabel kasus kekerasan anak yang diterima oleh Komisi Nasional Perlindungan Anak:

\section{Tabel Kasus Kekerasan Anak}

\begin{tabular}{|c|c|c|c|c|c|}
\hline \multirow{2}{*}{ KETERANGAN } & \multicolumn{5}{|c|}{ TAHUN } \\
\cline { 2 - 6 } & 2010 & 2011 & 2012 & 2013 & $2014^{*}$ \\
\hline $\begin{array}{c}\text { Laporan } \\
\text { Kekerasan }\end{array}$ & 2.413 & 2.508 & 2.637 & 2.792 & 3.339 \\
\hline
\end{tabular}

Keterangan :* Dari Januari sampai Mei 2014 Sumber:Data Komisi Nasional Perlindungan Anak dari tahun 2010-2014

Tabel diatas menunjukkan bahwa meningkatnya kasus kekerasan sesama anak dari tahun ke tahun tersebut menunjukkan belum tumbuhnya rasa

\footnotetext{
1 "Komnas PA Terima Laporan 3.339 Kasus Kekerasan Anak", www.news.okezone.com, (Jakarta, 06-052014).

${ }^{2}$ Dyah Ratna Meta Novia dan Muhammad Iqbal, Aduan Bullying Tertinggi, www.republika.com, (Jakarta, 15-10-2014).
}

solidaritas, kasih sayang dan kebersamaan. Perilaku bullying yang bahkan sampai menghilangkan nyawa menumbuhkan bibit gangguan kejiwaan kepada anak, baik korban maupun pelaku. Sulitnya menghentikan bullying karena korban biasanya pernah terlibat atau menjadi pelaku bullying terhadap orang lain. Menurut survei yang dilakukan oleh Latitude News pada 40 negara, bahwa ditemukan fakta seputar Bullying. Salah satu faktanya adalah bahwa pelaku bullying biasanya para siswa atau mahasiswa laki-laki. Sedangkan siswi atau mahasiswi lebih banyak menggosip ketimbang melakukan aksi kekerasan dengan fisik. ${ }^{3}$

Pada umumnya, anak laki-laki lebih banyak menggunakan bullying secara fisik dan anak wanita banyak menggunakan bullying relasional atau emosional, namun keduanya sama-sama menggunakan bullying verbal. Perbedaan ini, lebih berkaitan dengan pola sosialisasi yang terjadi antara anak laki-laki dan perempuan. ${ }^{4}$ Dari survei tersebut juga terdapat negara-negara dengan kasus bullying tertinggi di seluruh Dunia. Dan Indonesia masuk di urutan ke dua. Berikut negara-negara dengan kasus bullying tertinggi di Dunia:

1) Jepang.

2) Indonesia.

3) Kanada dan Amerika Serikat.

4) Finlandia. ${ }^{5}$

Di Indonesia sendiri ada beberapa kasus bullying yang sempat menjadi sorotan

\footnotetext{
${ }^{3}$ Barbara Coloroso, Penindas, Tertindas, dan Penonton; Resep Memutus Rantai Kekerasan Anak dari Prasekolah hingga SMU, (Jakarta: Serambi Ilmu Pustaka, 2006), hal.51.

${ }^{4}$ Ibid.

${ }^{5}$ Sikin Yolan, Negara-negara dengan Kasus Bullying

Tertinggi, Indonesia di Urutan Ke-2,

www.uniqpost.com, (Jakarta, 20-10-2012).
} 
publik dan melibatkan polisi. Seperti di Jakarta, kasus penindasan terhadap junior seperti tidak ada habisnya dari waktu ke waktu. Berikut 5 kasus yang sempat terkuak di publik dan diantaranya adalah sekolah ternama yaitu:

1) Kasus Bullying di SMA 90 Jakarta.

2) Kasus Bullying SMA 82 Jakarta.

3) Kasus Bullying SMA 46 Jakarta.

4) Kasus Bullying SMA 70 Jakarta.

5) Kasus Bullying SMA Don Bosco Pondok Indah. ${ }^{6}$

Dengan demikian dapat diketahui bahwa bullying merupakan permasalahan yang terjadi dalam lingkungan sosial secara keseluruhan. Serangan dari pelaku bullying terjadi dalam suatu konteks sosial dimana guru dan orangtua umumnya tidak menyadari permasalahan tersebut, dan para remaja lainnya rentan untuk terlibat dalam situasi bullying, sementara beberapa lainnya tidak mengetahui cara untuk keluar dari situasi tersebut. Seharusnya dengan adanya peningkatan kasus kekerasan pada anak tersebut diatas, menjadikan dorongan untuk pemerintah dalam mempercepat penyelesaian revisi Undang-Undang Perlindungan Anak.

\section{[BULLYING DALAM KALANGAN PELAJAR]}

Istilah kekerasan di kalangan pelajar, sejak tahun 1970 lebih dikenal dengan istilah bullying. Seorang pelajar dikatakan sebagai korban bullying ketika ia diketahui secara berulang-ulang terkena tindakan negatif oleh satu atau lebih banyak pelajar lain. Tindakan negatif tersebut termasuk melukai, atau mencoba melukai atau membuat korban merasa tidak nyaman dan dapat dilakukan secara fisik (pemukulan, tendangan, mendorong,

\footnotetext{
${ }^{6}$ Ibid.
}

mencekik, dll) atau secara verbal (memanggil dengan nama buruk, mengancam, mengolok-olok, jahil, menyebarkan isu buruk, dll.), serta tindakan lain seperti memasang muka dan melakukan gerakan tubuh yang melecehkan (secara seksual) atau secara terus menerus mengasingkan korban dari kelompoknya. $^{7}$

Namun, bullying sesama pelajar memiliki karakteristik berbeda dari kekerasan yang dilakukan oleh orang dewasa. Kekerasan yang dilakukan oleh orang dewasa terhadap anak biasanya dilakukan oleh pelaku tunggal sedangkan bullying oleh sesama murid biasanya berlangsung secara berkelompok. Bahkan menurut penelitian lintas negara yang dilakukan Craig dkk. "Anak yang menjadi korban bullying cenderung terlibat dalam penggencetan anak lain. Ini berarti sebuah lingkaran tanpa akhir ketika korban berubah menjadi pelaku. Dengan begitu, praktek kekerasan menjadi budaya di kalangan anak-anak." 8

Sepertinya, setiap pelajar pernah mengalami semua bentuk kekerasan di atas. Ada yang menjadi pelaku, korban atau paling tidak sebagai saksi. Bisa terjadi di sekolah maupun di luar sekolah, di sekolah umum, atau di pesantren. Bahkan, menurut pakar pendidikan, sekolah berasrama lebih rawan dalam hal tindak kekerasan. Kasus kekerasan di STPDN (kini IPDN) beberapa waktu yang lalu, membuktikan hipotesis tersebut. Definisi Bullying menurut PeKA (Peduli Karakter Anak) adalah "Penggunaan agresi dengan tujuan untuk menyakiti orang lain baik secara fisik maupun mental. Bullying dapat

\footnotetext{
${ }^{7}$ Ratna Djuwita, Kekerasan Tersembunyi di Sekolah: Aspek-aspek Psikososial dari Bullying. Makalah dalam Workshop Bullying: Masalah Tersembunyi dalam Dunia Pendidikan di Indonesia, (Jakarta,2006), hal. 2.

${ }^{8}$ Wendy Craig dkk, "A Cross-National Adolescents in 40 countries", (Int J Public Health,2009), hal.54; Suppl 2 hal.216-224.
} 
berupa tindakan fisik, verbal, emosional dan juga seksual."

Sedangkan menurut psikolog Andrew Mellor, bullying adalah "Pengalaman yang terjadi ketika seseorang merasa teraniaya oleh tindakan orang lain dan ia takut apabila perilaku buruk tersebut akan terjadi lagi sedangkan korban merasa tidak berdaya untuk mencegahnya. Bullying tidak lepas dari adanya kesenjangan power atau kekuatan antara korban dan pelaku serta diikuti pola repetisi (pengulangan perilaku)". ${ }^{10}$ Menurut Smith dan Thompson bully diartikan sebagai "Seperangkat tingkah laku yang dilakukan secara sengaja dan menyebabkan kecederaan fisik serta psikologikal yang menerimanya. Tingkah laku buli yang dimaksudkan termasuk tindakan yang bersifat mengejek, penyisihan sosial, dan memukul."11 Sementara itu, Tattum dan Tattum mengartikan bully sebagai "Keinginan untuk mencederakan, atau meletakkan seseorang dalam situasi yang tertekan." 12

Ada banyak definisi mengenai bullying, terutama yang terjadi dalam konteks lain (tempat kerja, masyarakat, komunitas virtual). Namun di sini saya akan membatasi konteksnya dalam school bullying atau bullying di kalangan pelajar.

Riauskina, Djuwita, dan Soesetio mendefinisikan school bullying sebagai "Perilaku agresif yang dilakukan berulangulang oleh seorang atau sekelompok pelajar yang memiliki kekuasaan, terhadap pelajar lain yang lebih lemah, dengan

\footnotetext{
${ }^{9}$ Retno Astuti Ponny, Meredam Bullying, (Jakarta: Grasindo, 2008), hal.3.

${ }^{10}$ SEJIWA, Bullying Mengatasi Kekerasan di Sekolah dan Lingkungan Sekitar Anak, (Jakarta:

Grasindo,2008), hal. 47.

${ }^{11}$ Smith, P.K. \& Thompson, D. (1991). Practical approaches to bullying, (London: David Fulton). ${ }^{12}$ Tattum, D. \& Tattum, E. (1992). Social education and personal development, (London: David Fulton).
}

tujuan menyakiti orang tersebut". Kemudian mereka mengelompokkan perilaku bullying ke dalam 5 kategori, yaitu:

a) Kontak fisik langsung (memukul, mendorong, menggigit, menjambak, menendang, mengunci seseorang dalam ruangan, mencubit, mencakar, juga termasuk memeras dan merusak barang-barang yang dimiliki orang lain).

b) Kontak verbal langsung (mengancam, mempermalukan, merendahkan, mengganggu, memberi panggilan nama (name-calling), sarkasme, merendahkan (put-downs), mencela/mengejek, mengintimidasi, memaki, menyebarkan gosip).

c) Perilaku non-verbal langsung (melihat dengan sinis, menjulurkan lidah, menampilkan ekspresi muka yang merendahkan, mengejek, atau mengancam; biasanya disertai oleh bullying fisik atau verbal).

d) Perilaku non-verbal tidak langsung (mendiamkan seseorang, memanipulasi persahabatan sehingga menjadi retak, sengaja mengucilkan atau mengabaikan, mengirimkan surat kaleng).

e) Pelecehan seksual (kadang dikategorikan perilaku agresi fisik atau verbal). ${ }^{13}$

Dengan demikian, dapat disimpulkan bahwa bullying berasal dari kata bully, yaitu suatu kata yang mengacu pada pengertian adanya "ancaman" yang dilakukan seseorang terhadap orang lain (yang umumnya lebih lemah atau

\footnotetext{
${ }^{13}$ Riauskina, Djuwita, R., dan Soesetio, S. R.

"Gencet-gencetan" di Mata Siswa/Siswi Kelas 1 SMA.

Naskah Kognitif tentang Arti, Skenario, dan Dampak

"Gencet-

gencetan", (Jurnal Psikologi Sosial 12 (01), 13

Januari 2005).
} 
"rendah" dari pelaku), yang menimbulkan gangguan psikis bagi korbannya berupa stress (yang muncul dalam bentuk gangguan fisik atau psikis, atau keduanya; misalnya susah makan, sakit fisik, ketakutan, rendah diri, depresi, cemas, dan lainnya). Apalagi Bully biasanya berlangsung dalam waktu yang lama (tahunan) sehingga sangat mungkin mempengaruhi korban secara psikis. Sedangkan bully dikalangan pelajar adalah perlakuan yang membuat tidak nyaman di lingkungan sekolah dengan menggunakan kekuasaan dan kekuatan yang dimiliki untuk menyakiti pelajar lainnya dalam bentuk verbal dan fisik.

Biasanya bully dilakukan oleh para senior ke junior yang terjadi di lingkungan sekolahnya. Hal tersebut dikarenakan mereka merasa dirinya berkuasa, ingin disegani dan ingin dihormati oleh juniornya. Pada umumnya mereka melakukannya dalam bentuk tindakan kekerasan seperti menampar, menjambak, meludahi, mengancam, memukul, serta menganiaya korban hingga korban tak berdaya. Bullying dapat mengakibatkan pelakunya terjerat hukum dan dapat dikeluarkan dari sekolah. Rigby menguraikan unsur-unsur yang terkandung dalam pengertian bullying dilingkungan pelajar yaitu antara lain keinginan untuk menyakiti, tindakan negatif, ketidakseimbangan kekuatan, pengulangan atau repetisi, bukan sekedar penggunaan kekuatan, kesenangan yang dirasakan oleh pelaku dan rasa tertekan di pihak korban. ${ }^{14}$

Bullying selain berpengaruh pada pelajar juga terhadap masyarakat. Bullying pada pelajar seringkali dicirikan dengan: "(a) para siswa yang merasa tidak aman di sekolah, (b) rasa tidak memiliki dan

\footnotetext{
${ }^{14}$ Ken Rigby, The Anti-Bullying and Teasing Book,
} (Australia:Gryphon House, Inc., 2005), hal. 51. ketidak-adaan hubungan dengan masyarakat sekolah, (c) ketidakpercayaan di antara para siswa, (d) pembentukan geng formal dan informal sebagai alat untuk menghasut tindakan bullying atau melindungi kelompok dari tindak bullying, (e) tindakan hukum yang diambil menentang sekolah yang dilakukan oleh siswa dan orang tua siswa, (f) turunnya reputasi sekolah di masyarakat, (g) rendahnya semangat juang staf dan meningginya stress pekerjaan, (g) dan iklim pendidikan yang buruk." 15

Di Indonesia, dari hasil penelitian yang dilakukan oleh Rahma Nuraini ditemukan beberapa karakteristik pelaku bullying yakni:

1) Suka mendominasi orang lain.

2) Suka memanfaatkan orang lain untuk mendapatkan apa yang mereka inginkan.

3) Sulit melihat situasi dari sudut pandang orang lain.

4) Hanya peduli pada kebutuhan dan kesenangan mereka sendiri.

5) Cenderung melukai anak-anak lain ketika tidak ada orang dewasa di sekitar mereka.

6) Memandang rekan yang lebih lemah sebagai mangsa.

7) Menggunakan kesalahan kritikan dan tuduhan-tuduhan yang keliru untuk memproyeksikan ketidakcakapan mereka kepada targetnya.

8) Tidak mau bertanggung jawab atas tindakannya.

9) Tidak memiliki pandangan terhadap masa depan, yaitu tidak mampu memikirkan konsekuensi dari tindakan yang mereka lakukan.

10) Haus perhatian. ${ }^{16}$

${ }^{15}$ Cherryl E. Sanders \& Phye Gary D., Bullying Implication for The Classroom, (California: Elsevier Academic Press, 2003), hal.29

${ }^{16}$ Rahma Nuraini, Perilaku Bullying di Sekolah Menengah Pertama. Skripsi di Jurusan Psikologi 
Perilaku bully merupakan tingkah laku yang kompleks. Anak-anak tidak dilahirkan untuk menjadi seorang pembully. Tingkah laku bully juga tidak diajarkan secara langsung kepada anakanak. Terdapat berbagai faktor yang mempengaruhi seorang anak berkembang menjadi pembully. Faktor-faktor penyebab adanya bullying di kalangan pelajar adalah sebagai berikut:

\section{a. Hubungan Keluarga}

Karena faktor orang tua di rumah yang tipe suka memaki, membandingkan atau melakukan kekerasan fisik. Anak pun menganggap benar bahasa kekerasan, maka ia mempelajari bahwa bullying adalah suatu perilaku yang bisa diterima dalam membina suatu hubungan atau dalam mencapai apa yang diinginkannya. ${ }^{17}$

b. Teman Sebaya

Berkenaan dengan faktor teman sebaya dan lingkungan sosial, terdapat beberapa penyebab pelaku bullying melakukan tindakan bullying adalah sbb:

- Kecemasan dan perasaan inferior dari seorang pelaku.

- Persaingan yang tidak relistis.

- Perasaan dendam yang muncul karena permusuhan atau juga karena pelaku bullying pernah menjadi korban bullying sebelumnya.

- Ketidakmampuan menangani emosi secara positif. ${ }^{18}$

c. Pengaruh Media

Survey yang dilakukan kompas memperlihatkan bahwa 56,9\% anak

Pendidikan dan Bimbingan UPI, (Bandung:2008), hal. 78 .

${ }^{17}$ Diena Haryana, Penelitian Mengenai Kekerasan di Sekolah, www.sejiwa.or.id, (Jakarta, 16/2007).

${ }^{18}$ Rahma Nuraini, Op.cit, hal.47. meniru adegan-adegan film yang ditontonnya, umumnya mereka meniru geraknya (64\%) dan kata-katanya $(43 \%){ }^{19}$

Adapun tindakan Bullying bisa terjadi dimana saja, terutama tempat-tempat yang tidak diawasi oleh guru atau orang dewasa lainnya. Pelaku akan memanfaatkan tempat yang sepi untuk menunjukkan "kekuasaannya" atas anak lain, agar tujuannya tercapai. Sekitar toilet sekolah, pekarangan sekolah, tempat menunggu kendaraan umum, lapangan parkir, bahkan mobil jemputan dapat menjadi tempat terjadinya Bullying. Bentuk bullying fisik termasuk persoalan serius dan membahayakan, tidak hanya terhadap korbannya tetapi juga pelaku dan saksi. Dampak bullying, sebagaimana menurut Victorian Departement of Education and Early Chilhood Development dapat terjadi pada:

(1) Pelaku, bullying yang terjadi pada tingkat SD dapat menjadi penyebab perilaku kekerasan pada jenjang pendidikan berikutnya; pelaku cenderung berperilaku agresif dan terlibat dalam geng serta aktivitas kenakalan lainnya; pelaku rentan terlibat dalam kasus kriminal saat menginjak usia remaja.

(2) Korban, memiliki masalah emosi, akademik, dan perilaku jangka panjang, cenderung memiliki harga diri yang rendah, lebih merasa tertekan, suka menyendiri, cemas, dan tidak aman, bullying menimbulkan berbagai masalah yang berhubungan dengan sekolah seperti tidak suka terhadap sekolah, membolos, dan drop out.

${ }^{19}$ Saripah, Model konseling kognitif untuk menanggulangi bullying siswa,, (Jurnal Psikologi Bandung: Universitas Pendidikan Indonesia), hal. 3. 
(3) Saksi, mengalami perasaan yang tidak menyenangkan dan mengalami tekanan psikologis yang berat, merasa terancam dan ketakutan akan menjadi korban selanjutnya, dapat mengalami prestasi yang rendah di kelas karena perhatian masih terfokus pada bagaimana cara menghindari menjadi target bullying dari pada tugas akademiknya. ${ }^{20}$

Oleh karena itu trauma korban bullying, dapat mengakibatkan seorang pelajar depresi dan tidak mau belajar di sekolah lagi. Hal ini sangat merugikan bagi masa depan anak, orang tua yang perduli dengan masa depan anak sebaiknya segera melakukan tindakan yang membantu penyembuhan anak korban bullying karena anak tersebut akan merasa nyaman ketika dia tidak berangkat kesekolah. Untuk itu melibatkan orang dewasa dalam penanggulangan dan pencegahan serta mendidik pelajar untuk bisa menjadi pribadi yang bisa menghadapi situasi yang menjurus kearah bullying atau kekerasan adalah hal yang sangat penting.

Dengan melihat uraian tersebut diatas, maka pencegahan bullying pelajar di sekolah harus dimulai dari saat ini baik oleh pemerintah, sekolah, orang tua dan juga pelajar itu sendiri. Pencegahan di lingkungan sekolah bisa berupa tindakan memperbaiki hubungan interpersonal individu dalam sekolah dengan melibatkan partisipasi guru, orang tua, pelajar, serta orang dewasa lain yang ada dalam sekolah.

${ }^{20}$ Victorian Departement of Education and Early Chilhood Development, (Melbourne, November 2009).

\section{[TINJAUAN KRIMINOLOGI TERHADAP BULLYING PELAJAR]}

Tidak ada satu pun makhluk hidup yang menginginkan adanya kriminalitas seperti kekerasan, intimidasi, pelecehan seksual, penganiayaan, bahkan pemerkosaan. Segala bentuk tindak kriminal yang identik dengan kekerasan bisa disebut dengan bully. Istilah bully berasal dari Bahasa Inggris yang artinya kekerasan atau intimidasi. Beragam bentuk bully yaitu fisik maupun verbal. Fisik bisa berupa pemukulan, penganiayaan, pelecehan seksual, pemerkosaan, dsb. Sedangkan yang tergolong verbal yaitu penghinaan, diskriminasi, bentakan, pemalakan, dan segala macam bentuk tindakan yang bertujuan mempermalukan atau memojokkan korban.

Bullying dalam bentuk tindak penyiksaan dan pembunuhan, tentu sudah masuk ke dalam tindak pidana kriminalisme. Bahkan mungkin masyarakat belum mengetahui bahwa tindak bullying tahap awal seperti menghina, mencaci, dan mengucilkan seseorang juga sudah termasuk dalam tindak kriminal yang dapat dikenakan Pasal 335 KUHP Tentang Perbuatan Tidak Menyenangkan. Walaupun pasal tersebut akan lebih sulit diajukan terkait bukti yang tidak seakurat kasus bullying penyiksaan dan pembunuhan. Suatu hal yang pasti apabila memandang bullying sebagai suatu kejahatan, dikarenakan unsur-unsur yang ada di dalam bullying itu sendiri.

Ken Rigby menguraikan unsur-unsur yang terkandung dalam pengertian bullying yaitu antara lain "Keinginan untuk menyakiti, tindakan negatif, ketidakseimbangan kekuatan, pengulangan atau repetisi, bukan sekedar penggunaan kekuatan, kesenangan yang dirasakan oleh pelaku dan rasa tertekan di pihak 
korban." ${ }^{21}$ Menurut Seto Mulyadi, yang lebih mengkhawatirkan adalah seorang anak (pelaku) bullying berpotensi tumbuh sebagai pelaku kriminal dibanding yang tidak melakukan bullying. Seto Mulyadi juga mengatakan bahwa sampai saat ini data mengenai bullying masih sulit diungkap karena dilakukan secara sembunyi dan luput dari perhatian orang tua atau pun guru dan hanya dianggap sebagai kenakalan anak biasa. ${ }^{22}$

Gunarso mengatakan dari segi hukum, kenakalan remaja termasuk bullying digolongkan dalam dua kelompok yang berkaitan dengan norma-norma hukum yaitu :

(1) Kenakalan yang bersifat amoral dan sosial serta tidak diantar dalam undang-undang sehingga tidak dapat atau sulit digolongkan sebagai pelanggaran hukum;

(2) Kenakalan yang bersifat melanggar hukum dengan penyelesaian sesuai dengan undang-undang dan hukum yang berlaku sama dengan perbuatan melanggar hukum bila dilakukan orang dewasa. ${ }^{23}$

Kartini Kartono juga secara tegas dan jelas memberikan batasan kenakalan remaja (bullying) merupakan "Gejala sakit secara sosial pada anak-anak dan remaja yang disebabkan oleh bentuk pengabaian sosial, sehingga mereka itu mengembangkan bentuk tingkah laku yang menyimpang. Perilaku anak-anak ini menunjukkan kurang atau tidak adanya konformitas terhadap norma-norma sosial." ${ }^{24}$ Dapat diketahui di dalam cabang

\footnotetext{
${ }^{21}$ Ken Rigby, Op.cit, hal.51.

${ }^{22}$ Seto Mulyadi (Admin, 2007),

${ }^{23}$ Gunarso Singgih D, Psikologi Remaja, (Jakarta: BPK Gunung Mulya, 1988), hal. 18.

${ }^{24}$ Kartini Kartono, Patologi Sosial, Kenakalan Remaja, (Jakarta: Raja Grafindo Persada,2003), hal 6.
}

Ilmu Sosiologi Hukum dikenal beberapa teori yang sesuai dengan perilaku bullying dikalangan pelajar sebagai bentuk gejala kejahatan anak, diantaranya sebagai berikut:

\section{a. Teori Labeling (Micholowsky)}

Edwin Lemert membedakan tiga penyimpangan dalam kekerasan pelajar, yaitu:

- Individual deviation, di mana timbulnya penyimpangan diakibatkan oleh karena tekanan psikis dari dalam;

- Situational deviation, sebagai hasil stres atau tekanan dari keadaan; dan

- Systematic deviation, sebagai pola pola perilaku kejahatan terorganisir dalam sub-sub kultur atau sistem tingkah laku.

Pada dasarnya teori labeling pada kasus bullying pelajar menggambarkan:

- Tidak ada satupun perbuatan yang pada dasarnya bersifat kriminal;

- Predikat kejahatan dilakukan oleh kelompok yang dominan atau kelompok penguasa;

- Penerapan aturan tentang kejahatan dilakukan untuk kepentingan pihak yang berkuasa;

- Orang tidak menjadi penjahat karena melanggar hukum, tetapi karena ditetapkan demikian oleh penguasa; dan

- Pada dasarnya semua orang pernah melakukan kejahatan, sehingga tidak patut jika dibuat kategori orang jahat dan orang tidak jahat. Premis tersebut menggambarkan bahwa sesungguhnya tidak ada orang yang bisa dikatakan jahat apabila tidak terdapat aturan yang dibat oleh penguasa untuk menyatakan bahwa sesuatu 
tindakan yang dilakukan seseorang atau sekelompok orang diklasifikasikan sebagai kejahatan.

\section{b. Differential Assosiation Theory}

\section{(Edwin H. Sutherland)}

Sembilan premis perilaku jahat (bullying) di kalangan pelajar adalah:

- Perilaku kejahatan adalah perilaku yang dipelajari, bukan warisan.

- Perilaku kejahatan dipelajari dalam interaksi dengan orang lain dalam suatu proses komunikasi. Komunikasi tersebut dapat bersifat lisan atau dengan bahasa tubuh).

- Bagian terpenting dalam proses mempelajari perilaku kejahatan terjadi dalam hubungan personal yang intim. Secara negatif ini berarti bahwa komunikasi interpersonal seperti melalui bioskop, surat kabar, secara relatif tidak berperanan penting dalam terjadinya kejahatan.

- Ketika perilaku kejahatan dipelajari, maka yang dipelajari termasuk: teknik melakukan kejahatan, motif-motif, dorongan dorongan, alasan-alasan pembenar dan sikap-sikap tertentu).

- Arah dan motif dorongan itu dipelajari melalui definisi-definisi dari peraturan hukum. Dalam suatu masyarakat, kadang seseorang dikelilingi oleh orang orang yang secara bersamaan melihat apa yang diatur dalam peraturan hukum sebagai sesuatu yang perlu diperhatikan dan dipatuhi, namun kadang ia dikelilingi orang-orang yang melihat aturan hukurn sebagai sesuatu yang memberikan peluang dilakukannya kejahatan.

- Seseorang menjadi delinkuen karena ekses pola-pola pikir yang lebih melihat aturan hukurn sebagai pernberi peluang melakukan kejahatan daripada melihat hukum sebagai sesuatu yang harus diperhatikan dan dipatuhi.

- Asosiasi Diferensial bervariasi dalam frekuensi, durasi, prioritas serta intensitasnya.

- Proses mempelajari perilaku jahat diperoleh lewat hubungan dengan pola-pola kejahatan dan mekanisme yang lazim terjadi dalam setiap proses belajar secara umum.

- Sementara itu perilaku jahat merupakan ekspresi dari kebutuhan nilai umum, namun tidak dijelaskan bahwa perilaku yang bukan jahatpun merupakan ekspresi dari kebutuhan dan nilainilai umum yang sama.

\section{Undang - Undang Perlindungan Anak Sebagai Landasan Anti-Bullying}

Meskipun tidak ada peraturan mewajibkan sekolah harus memiliki kebijakan program anti bullying, tetapi dalam undang-undang perlindungan anak No. 23 Tahun 2002 pasal 54 dinyatakan: "Anak di dalam dan di lingkungan sekolah wajib dilindungi dari tindakan kekerasan yang dilakukan oleh guru, pengelola sekolah atau temantemannya di dalam sekolah yang bersangkutan, atau lembaga pendidikan lainnya."

Dengan kata lain, siswa mempunyai hak untuk mendapat pendidikan dalam lingkungan yang aman dan bebas dari rasa takut. Pengelola Sekolah dan pihak lain yang bertanggung jawab dalam penyelengaraan pendidikan mempunyai tugas untuk melindungi siswa dari intimidasi, penyerangan, kekerasan atau gangguan. Yang dimaksud dengan anak 
dalam undang-undang perlindungan anak No.23 Tahun 2002 adalah seseorang yang belum berusia 18 (delapan belas) tahun, termasuk anak yang masih dalam kandungan (Pasal 1 ayat 1 ).

\section{[PENCEGAHAN BULLYING DI KALANGAN PELAJAR]}

Perilaku bully merupakan satu dari banyak masalah tingkah laku dan disiplin di kalangan murid sekolah dewasa ini. Perilaku bully secara langsung atau tidak langsung merupakan sebagian dari tingkah laku agresi. Perilaku bully terjadi jika terdapat perbedaan atau ketidakseimbangan kuasa antara pembully dengan korban. Terdapat beberapa faktor yang mendorong terjadinya perilaku bully di kalangan pelajar atau murid sekolah, yaitu faktor individu, keluarga, teman sebaya, sekolah dan media. Perilaku bully perlu dicegah terutama terjadi di sekolah. Oleh karena itu sekolah perlu memiliki program baik program pencegahan maupun program intervensi pemulihan yang melibatkan semua komponen yang terlibat dalam proses belajar mengajar di sekolah.

Wakil Gubernur DKI Jakarta Prijanto menawarkan konsep pembentukan karakter bagi para siswa. Terutama dalam meningkatkan rasa kepekaan terhadap sesama. "Mereka itu perlu pembentukan suatu karakter atau perilaku untuk bisa pahami orang lain, saya bilang coba anakanak sekolah itu bawa ke tempat orang miskin dan tempat umum agar mereka tergugah bahwa ada lingkungan yang tidak sebaik mereka."25 Sementara itu hasil diskusi Bullying di The Center For The Betterment Of Education, Save The Children, Jakarta 12 Januari 2010,

${ }^{25}$ Bullying dan Salusinya, www.harunnihaya.blagspat.com, (Jakarta, 28-(10-201I). memberikan beberapa solusi dan rekomendasi dalam rangka mengurangi bullying di sekolah, yaitu:

1) Sosialisasi antibullying kepada siswa, guru, orang tua siswa, dan segenap pelaku akademika di sekolah.

2) Penerapan aturan di sekolah yang mengakomodasi aspek antibullying.

3) Membuat aturan antibullying yang disepakati oleh siswa, guru, institusi sekolah dan semua pelaku akademika institusi pendidikan/ sekolah.

4) Penegakan aturan/sanksi/disiplin sesuai kesepakatan institusi sekolah dan siswa, guru dan sekolah, serta orang tua dan dilaksanakan sesuai dengan prosedur pemberian sanksi.

5) Membangun komunikasi dan interaksi antar pelaku akademika.

6) Meminta Depdiknas memasukkan muatan kurikulum pendidikan nasional yang sesuai dengan tahapan perkembangan kognitif anak/siswa agar tidak terjadi learning difficulties.

7) Pendidikan parenting agar orang tua memiliki pola asuh yang benar.

8) Mendesak Depdiknas memasukkan muatan kurikulum institusi pendidikan guru yang mengakomodasi antibullying.

9) Muatan media cetak, elektronik, film, dan internet tidak memuat bullying dan mendesak Komisi Penyiaran Indonesia (KPI) mengawasi siaran yang memasukkan unsur bullying.

10) Perlunya kemudahan akses orang tua atau publik, lembaga terkait, ke institusi pendidikan/sekolah sebagai bentuk pengawasan untuk pencegahan dan penyelesaian bullying atau dibentuknya pos pengaduan bullying. ${ }^{26}$ 
Cara mencegah supaya anak tidak menjadi pelaku bullying adalah jika sekolah dan orangtua memiliki pemahaman yang menyeluruh mengenai anak. Kunci utama dari antisipasi masalah disiplin dan bullying adalah adanya hubungan yang baik dengan anak. Hubungan yang baik akan membuat anak terbuka dan percaya bahwa setiap masalah yang dihadapinya akan dapat diatasi dan orangtua dan guru akan selalu siap membantunya. Dari sinilah anak kemudian belajar untuk menyelesaikan masalah dengan cara yang tepat. Sedangkan cara bagaimana supaya anak tidak menjadi korban bullying yaitu berkaitan erat dengan konsep diri anak. Jika anak memiliki konsep diri yang baik, dalam artian anak tersebut mengenal betul kelebihan dan kekurangan dirinya, ia tidak akan terganggu dengan tekanan-tekanan dari teman-teman atau pelaku bullying. Biasanya apabila korban atau calon korban tidak menggubris, pelaku bullying tidak akan mendekatinya lagi. Dan yang paling penting adalah membekali anak dengan keterampilan asertif, sehingga bisa memberikan pesan yang tepat pada pelaku bahwa dirinya bukan pihak yang bisa dijadikan korban.

Oleh karena itu pencarian identitas diri yang positif akan mengarah pada pengembangan potensi yang dimiliki remaja ke arah yang lebih baik, sedangkan pencarian identitas diri yang negatif biasanya diekspresikan remaja dalam bentuk tingkah laku, seperti tawuran, penyalahgunaan obat-obatan, pacaran sampai prestasi yang menurun. Proses pembentukan identitas diri memiliki kaitan erat dengan bagaimana remaja menilai atau mengevaluasi diri karena perkembangan self esteem pada seorang remaja akan menentukan keberhasilan maupun kegagalannya di masa mendatang. ${ }^{27}$ Dengan demikian menurut saya, cara paling ideal untuk mencegah terjadinya bullying:

- Mengajarkan kemampuan asertif, yaitu kemampuan untuk menyampaikan pendapat atau opini pada orang lain dengan cara yang tepat. Hal ini termasuk kemampuan untuk mengatakan tidak atas tekanan-tekanan yang didapatkan dari pelaku bullying.

- Sekolah meningkatkan kesadaran akan adanya perilaku bullying (tidak semua anak paham apakah sebenarnya bullying itu) dan bahwa sekolah memiliki dan menjalankan kebijakan anti bullying. Murid harus bisa percaya bahwa jika ia menjadi korban, ia akan mendapatkan pertolongan. Sebaliknya, jika ia menjadi pelaku, sekolah juga akan bekerjasama dengan orangtua agar bisa bersama-sama membantu mengatasi permasalahannya.

- Memutus lingkaran konflik dan mendukung sikap bekerjasama antar anggota komunitas sekolah, tidak hanya interaksi antar murid dalam level yang sama tapi juga dari level yang berbeda.

Perlunya penegakan hukum yang keras terhadap pelaku kekerasan anak atau bullying, terutama jika menyebabkan kematian. Konsep pelindungan anak seharusnya tidak melindungi dirinya dari menebus kesalahan yang diperbuat, melihat dari usianya yang masih belia, perilaku membunuh tetap mengubah dinamika kepribadian seorang anak. Maka pelaku bullying perlu mendapatkan hukuman yang membuatnya jera dengan prinsip sesuai yang dimasukkan dalam Undang Undang No. 11 Tahun 2012 tentang Sistem Peradilan Pidana Anak.

${ }^{27}$ J.W Santrack, Remaja (Edisi ke-// Jilid Satu), (Jakarta: Erlangga, 2007). hal. 184. 
Selain itu, sekolah harus diberikan sanksi tegas untuk memutuskan mata rantai bullying di dunia pendidikan. Untuk itu Komisi X DPR RI perlu mendorong Kementerian terkait agar segera menyelesaikan kasus-kasus kekerasan sesama anak dengan resolusi terbaik. Selanjutnya revisi Undang-undang perlindungan anak yang telah lama tertunda harus segera dikaji kembali dan memasukan materi-materi pelindungan korban dan pelaku kekerasan sesama anak.

\section{[KESIMPULAN]}

Dapat disimpulkan bahwa bullying merupakan serangan berulang secara fisik, psikologis, sosial, ataupun verbal, yang dilakukan dalam posisi kekuatan yang secara situasional didefinisikan untuk keuntungan atau kepuasan mereka sendiri. Bullying merupakan bentuk awal dari perilaku agresif yaitu tingkah laku yang kasar. Bisa secara fisik, psikis, melalui kata-kata, ataupun kombinasi dari ketiganya. Hal tersebut dapat dilakukan oleh kelompok atau individu. Pelaku bully mengambil keuntungan dari orang lain yang dilihatnya mudah diserang. Tindakannya bisa dengan mengejek nama, korban diganggu atau diasingkan sehingga dapat merugikan korban.

Perilaku bullying di kalangan pelajar adalah sebuah bentuk perilaku yang menyimpang dan berbahaya, sehingga penanganan bullying harus dilakukan secara intensif. Bullying dapat terjadi di mana saja, terhadap siapa saja, dan bisa terjadi di semua lingkungan sekolah, tanpa ditentukan oleh batasan ukuran maupun tipe sekolah. Bagi beberapa orang bullying adalah masalah yang bersifat sementara, tetapi bagi yang lain bullying bisa membayangi seumur hidup. Pencegahan masalah kekerasan pelajar di sekolah (bullying) harus dimulai dari segala arah mulai dari keluarga, sekolah, pemerintah dengan kebijakan media massa terutama film-film hiburan yang sarat dengan kekerasan (bullying) dan semua pihak yang berkehendak baik untuk mengurangi bullying di sekolah.

Berdasarkan teori kriminologi, bentukbentuk kenakalan remaja termasuk bullying dapat dilihat dengan adanya gejala: berbohong, membolos, kabur, keluyuran, bersenjata tajam, pergaulan buruk, suka hura-hura, pesta pora yang siasia, membaca pornografi, mengkompas, melacurkan diri, dan bentuk-bentuk kenakalan remaja yang menjurus pada tindak kejahatan. Bentuk bullying yang termasuk dalam tindak kejahatan diselesaikan sesuai dengan prosedur hukum yang berlaku. Faktor-faktor penyebab terjadinya bullying dikelompokkan menjadi dua yaitu, pertama: faktor internal, yakni faktor penyebab dari dalam diri remaja. Kedua: faktor eksternal, yakni faktor penyebab yang berasal dari luar remaja, seperti: lingkungan keluarga, lingkungan sekolah, dan lingkungan masyarakat. Tingkah laku bully yang termasuk kenakalan remaja dapat berpengaruh negatif terhadap diri remaja, keluarganya, maupun masyarakatnya. Kenakalan remaja termasuk bullying dapat dikelompokkan menjadi dua yaitu, pertama, kenakalan remaja yang bersifat a-sosial dan a-moral yang belum diatur dalam hukum negara, dan kedua, kenakalan remaja yang bersifat pelanggaran hukum dan sudah diatur dalam hukum negara.

Penanganan bullying pelajar di sekolah harus meliputi berbagai aspek termasuk individual, akademik, kultural, dan sosial. Solusi masalah bullying di sekolah sama seperti masalah-masalah lain di sekolah yaitu terkait dengan disiplin. Semua pihak 
harus bertanggung jawab terhadap keadaan bullying di sekolah termasuk guru, orang tua dan murid itu sendiri. Setiap lingkungan sekolah manapun yang mengabaikan, membiarkan, atau menyangkal adanya masalah bullying akan merugikan komunitas sekolah itu sendiri. Hal ini memberikan kesan bahwa komunitas sekolah tersebut tidak memberikan perhatian terhadap anak-anak dan kaum minoritas. Sekolah semacam itu tidak akan memiliki budaya yang saling menghargai satu sama lain.

\section{DAFTAR PUSTAKA}

\section{$\underline{B U K U}$}

Astuti, Ponny Retno. Meredam Bullying. Jakarta: Grasindo, 2008.

Coloroso, Barbara. Penindas, Tertindas, dan Penonton; Resep Memutus Rantai Kekerasan Anak dari Prasekolah hingga SMU. Jakarta: Serambi Ilmu Pustaka, 2006

Craig, Wendy, dkk. "A Cross-National Adolescents in 40 countries". Int J Public Health, 2009.

Djuwita, Ratna. Kekerasan Tersembunyi di Sekolah: Aspek-aspek Psikososial dari Bullying. Makalah dalam Workshop Bullying: Masalah Tersembunyi dalam Dunia Pendidikan di Indonesia. Jakarta 29 April 2006.

Kartono, Kartini. Patologi Sosial, Kenakalan Remaja. Jakarta: Raja Grafindo Persada, 2003.

Nuraini, R. Perilaku Bullying di Sekolah Menengah Pertama. Skripsi di Jurusan Psikologi Pendidikan dan Bimbingan UPI Bandung, 2008.

Riauskina, I. I., Djuwita, R., dan Soesetio, S. R. "Gencet-gencetan" di Mata
Siswa/Siswi Kelas 1 SMA: Naskah Kognitif tentang Arti, Skenario, dan Dampak "Gencet-gencetan". Jurnal Psikologi Sosial 12 (01), 13 Januari 2005.

Rigby, Ken. The Anti-Bullying and Teasing Book. Australia: Gryphon House, Inc, 2005.

Santrock, J.W. Remaja (Edisi ke-11 Jilid Satu). Jakarta: Erlangga, 2007.

Sanders, Cherryl E. \& Gary D. Phye. Bullying Implication for The Classroom. California: Elsevier Academic Press, 2004.

SEJIWA, Bullying Mengatasi Kekerasan di Sekolah dan Lingkungan Sekitar Anak, Jakarta: Grasindo,2008.

Saripah, I. (2010). Model konseling kognitif untuk menanggulangi bullying siswa. Jurnal Psikologi. Bandung: Universitas Pendidikan Indonesia.

Singgih D, Gunarso. Psikologi Remaja. Jakarta : BPK Gunung Mulya, 1988.

Smith, P.K. \& Thompson, D. Practical approaches to bullying. London: David Fulton, 1991.

Tattum, D. \& Tattum. E. Social education and personal development. London: David Fulton, 1992.

Wendy Craig dkk. "A Cross-National Adolescents in 40 countries", (Int J Public Health,2009.

\section{INTERNET}

Haryana, Diena, Penelitian Mengenai Kekerasan di Sekolah, www.sejiwa.or.id, Jakarta, 16/2007. 
Ratna, Dyah, Novia, Meta dan Iqbal, Muhammad, Aduan Bullying Tertinggi, www.republika.com, Jakarta, 15 Oktober 2014.

Yolan, Sikin. Negara-negara dengan Kasus Bullying Tertinggi, Indonesia di Urutan Ke-2, www.uniqpost.com, Jakarta, 20 Oktober 2012).

Victorian Departement of Education and Early Chilhood Development, Melbourne, November 2009.

www.harunnihaya.blogspot.com. Bullying dan Solusinya, Jakarta, 28 Oktober 2011. 